\title{
AKTIVITAS ANTIOKSIDAN KRIM EKSTRAK ETIL ASETAT KULIT JERUK NIPIS (Citrus aurantifolia) YANG DITETAPKAN DENGAN METODE DPPH
}

\author{
The Antioxidant Activity Of The Lime Peel (Citrus aurantifolia) Ethyl Acetate Extract Determined By \\ The DPPH Method
}

\author{
Nurisyah $^{1 *}$, Asyhari Asyikin, Harpolia Cartika² \\ ${ }^{1}$ Jurusan Farmasi Politeknik Kesehatan Kemenkes Makassar \\ ${ }^{2}$ Jurusan Farmasi Poltekkes Kemenkes Jakarta 2 \\ *Koresponden Email : nurisyah31@gmail.com
}

DOI: https://doi.org/10.32382/mf.v16i2.1818

\section{ABSTRACT}

Lime peel (Citrus aurantifolia) contains flavonoids as antioxidants that prevent free radicals, and antioxidants are used to repair skin cells damaged by free radicals. Therefore, a research was conducted with the aim of formulating antioxidant cream preparations using lime peel extract. The extraction was carried out by maceration using ethanol $96 \%$ solvent, which was then fractionated with ethyl acetate as solvent. The ethyl acetate extract obtained was formulated into cream preparations with extract concentrations of 3\%, 6\%, and 9\%. The formula obtained was tested for its physical and stability, and then for its antioxidant activity. The results showed that the physical properties of the cream preparation meet with requirements for the physical stability based on the organoleptic test parameters, homogeneity, pH and viscosity. Similarly, the antioxidant activity test of cream against the DPPH free radicals showed that formula 1 with an extract concentration of $3 \%$ gives an average IC 50 value of $28.24 \mathrm{mg} / \mathrm{ml}$; formula 2 with an extract concentration of $6 \%$ gives an average $I C_{50}$ value of $22.97 \mathrm{mg} / \mathrm{ml}$; and formula 3 with an extract concentration of $9 \%$ gives an average IC $C_{50}$ value of $14.80 \mathrm{mg} / \mathrm{ml}$. Based on the results, it was concluded that the lime peel extract are formulated into a cream preparation with type M/A. Formula 3 with an extract concentration of $9 \%$ is the best formula with the greatest antioxidant activity.

Keywords :antioxidant, ethyl acetate, extract, lime peel, cream

\begin{abstract}
ABSTRAK
Kulit jeruk nipis (Citrus aurantifolia) mengandung flavonoid yang berfungsi sebagai antioksidan yang dapat menangkal radikal bebas. Antioksidan dapat dimanfaatkan untuk memperbaiki sel-sel kulit yang rusak akibat radikal bebas dan menangkal radikal bebas. Oleh karena itu dilakukan penelitian dengan tujuan untuk memformulasi sediaan krim antioksidan dengan menggunakan ekstrak kulit jeruk nipis. Ekstraksi dilakukan secara maserasi menggunakan pelarut etanol $96 \%$, yang selanjutnya difraksinasi dengan pelarut etil asetat. Ekstrak etil asetat yang diperoleh diformulasi menjadi sediaan krim dengan konsentrasi ekstrak $3 \%, 6 \%$, dan 9\%. Formula yang diperoleh diuji fisik dan stabilitasnya, selanjutnya dilakukan uji aktivitas antioksidannya. Hasil penelitian menunjukkan bahwa sifat fisik sediaan krim yang dihasilkan memenuhi syarat kestabilan fisik berdasarkan parameter uji organoleptik, homogenitas, $\mathrm{pH}$ dan viskositas. Uji aktivitas antioksidan krim terhadap radikal bebas DPPH menunjukkan bahwa formula 1 dengan konsentrasi ekstrak $3 \%$ memberikan nilai $\mathrm{IC}_{50}$ rata-rata sebesar $28,24 \mathrm{mg} / \mathrm{ml}$; formula 2 dengan konsentrasi ekstrak $6 \%$ memberikan nilai $\mathrm{IC}_{50}$ rata-rata sebesar $22,97 \mathrm{mg} / \mathrm{ml}$; dan formula 3 dengan konsentrasi ekstrak $9 \%$ memberikan nilai $\mathrm{IC}_{50}$ rata-rata sebesar $14,80 \mathrm{mg} / \mathrm{ml}$. Berdasarkan hasil penelitian ini maka dapat disimpulkan bahwa ekstrak kulit jeruk nipis dapat diformulasikan menjadi sediaan krim dengan tipe M/A, Formula 3 dengan konsentrasi ekstrak sebesar 9\% adalah formula terbaik dengan aktivitas antioksidan paling besar.
\end{abstract}

Kata kunci : antioksidan, etil asetat, ekstrak, kulit jeruk nipis, krim

\section{PENDAHULUAN}

Kaum wanita diseluruh dunia, termasuk di Indonesia banyak menggunakan kosmetik yang bertujuan untuk merawat dan mencerahkan kulit, termasuk Indonesia yang merupakan negara tropis dibelahan benua Asia Tenggara dengan suhu udara berkisar antara $25-35^{\circ} \mathrm{C}$ dan paparan sinar matahari yang menyengat 
sepanjang waktu dimana kandungan radiasi sinar ultraviolet dan faktor-faktor lainnya dapat mempercepat penuaan kulit disertai berkurangnya kelembaban kulit, elastisitas kulit, serta pigmentasi yang cepat muncul.

Selain paparan sinar matahari, paparan lain yang terjadi di kota besar adalah polusi. Di perkotaan, paparan polusi menjadi salah satu masalah yang terbesar yang dapat menyebabkan kulit menjadi lebih cepat rusak, teriritasi dan menua, disertai dengan timbulnya penyakit kulit antara lain eksim dan jerawat.

Salah satu penyebab penuaan kulit karena polusi adalah stress oksidatif yang disebabkan oleh karena radikal bebas yang terdapat dalam polutan, salah satu cara untuk mencegah efek dari radikal bebas adalah dengan menggunakan produk pelindung matahari serta dengan pemakaian produk yang mengandung antioksidan seperti polifenol (Pojsak \& Dahmane, 2011). Asupan antioksidan didapat secara oral ataupun topikal dengan dioleskan pada kulit (Pinnel, 2003). Asupan antioksidan dapat diperoleh secara alami maupun sintetik.

Salah satu cara untuk menghasilkan produk dengan nilai jual yang tinggi serta kreativitas yang bagus dan modal yang rendah yaitu dengan pengolahan limbah yang ada di lingkungan sekitar, di samping dapat membantu mengurangi pencemaran lingkungan, juga dengan cara ini, produk yang bernilai jual tinggi dan ramah terhadap lingkungan dapat dapat dihasilkan dengan tetap menjaga kelestarian lingkungan. Salah satu limbah lingkungan yang akan dimanfaatkan sebagai hasil produk yang memiliki nilai jual yang cukup tinggi dan ramah terhadap lingkungan ialah limbah kulit jeruk nipis.

Selama ini, kulit jeruk nipis masih dipandang sebagai bagian yang tidak diperlukan baik pada saat mengkonsumsi jeruk nipis segar untuk dijadikan sebagai makanan, obat tradisional, jus jeruk nipis, dan penambah cita rasa pada makanan, dimana bagian jeruk nipis sering digunakan adalah daging jeruk nipis. Pada tahun 2013, jumlah kulit jeruk di Indonesia mencapai 309.678 ton tiap tahunnya. Sejauh ini belum banyak orang yang mampu memanfaatkan limbah kulit jeruk tersebut, agar menambah nilai jualnya (Litbang Pertanian, 2013). Kulit jeruk nipis yang berlimpah, mudah didapat dan pemanfaatannya yang belum maksimal, menjadikan limbah tersebut tepat sebagai bahan aktif kosmetika anti aging.

Berdasarkan penelitian sebelumnya, kulit buah jeruk nipis kaya akan komponen flavonoid, tannin dan kumarin (Astarini, et al., 2010). Flavonoid merupakan salah satu golongan metabolit sekunder yang dihasilkan oleh tanaman yang termasuk dalam kelompok besar polifenol. Senyawa ini terdapat pada semua bagian tanaman termasuk daun, akar, kayu, kulit, tepung sari, nektar, bunga, buah, dan biji. Flavonoid mempunyai kemampuan sebagai penangkap radikal bebas dan menghambat oksidasi lipid (Banjarnahor \& Artanti, 2014; Treml \& Smejkal, 2016). Hal ini mendukung penelitian yang dilakukan oleh Nurisyah dan Asmawiyah (2018) menunjukkan bahwa ekstrak etil asetat limbah kulit jeruk nipis memiliki nilai $\mathrm{IC}_{50}$ sebesar $0,492 \mathrm{mg} / \mathrm{mL}$ Penelitian lain yang dilakukan oleh Hindun, et al. (2017) menyatakan bahwa ekstrak etanol kulit jeruk nipis memiliki potensi sebagai inhibisi tirosinase dengan nilai $\mathrm{IC}_{50}$ sebesar $42,11 \mathrm{mg} / \mathrm{mL}$. Hal ini yang mendasari kenapa formula yang dibuat pada penelitian ini menggunakan ekstrak etil asetat dari kulit jeruk nipis.

Berdasarkan latar belakang di atas, maka maka akan dibuat formula krim dan menguji aktivitas antioksidan sediaan krim tersebut. Formula krim yang dibuat adalah tipe minyak dalam air (m/a) karena merupakan sistem penghantaran optimal untuk bahan aktif polifenol dan lebih acceptable karena mudah diaplikasikan ke kulit serta meninggalkan rasa nyaman dibanding krim tipe air dalam minyak (a/m) (Bernatoniene, et al., 2011).

\section{METODE}

\section{Desain, tempat dan waktu}

Penelitian ini merupakan penelitian eksperimen laboratorium yang dilakukan di Laboratorium Teknologi Farmasi dan Laboratorium Kimia Jurusan Farmasi tahun 2019.

\section{Bahan dan Alat}

Bahan yang digunakan adalah Jeruk nipis (Citrus aurantifolia) diperoleh dari Sungguminasa Kabupten Gowa. Buah jeruk nipis dipilih yang telah matang, yaitu yang berwarna kuning kehijauan. DPPH (1,1Diphenyl-2-picrylhydrazyl) (Sigma Co.), etanol, etil asetat, asam stearat, setil alkohol, lanolin, Tween 80, Span 80, Tocoferol, nipagin, nipasol (Bratako) dan akuades.

Alat yang digunakan adalah Spektrofotometer UV-Vis (Agilent 8453), neraca analitik, blender, kertas saring, corong pisah, rotavapor, mikropipet, labu ukur, beker gelas, Erlenmeyer, bath sonicator (Branson tipe 5510), penangas air.

\section{Langkah-Langkah Penelitian \\ Pembuatan ekstrak kulit jeruk nipis (KJN)}

Jeruk nipis dicuci lalu dipisahkan kulit 
dan isinya, dipotong-potong kecil. Kemudian dijemur terlindung dari cahaya matahari langsung, dihaluskan dengan cara diblender. Kemudian sampel kulit jeruk nipis diekstraksi dengan pelarut etanol $96 \%$ secara maserasi. ekstrak etanol diuapkan dengan rotavapor dan difraksinasi dengan pelarut etil asetat. ekstrak etil asetat diuapkan hingga kering diatas penangas air suhu $70{ }^{\circ} \mathrm{C}$.

\section{Formulasi sediaan krim}

Ekstrak etil asetat yang diperoleh diformulasi untuk membuat sediaan krim sesuai formula berikut :

Rancangan Formula

\begin{tabular}{lcccc}
\hline \multicolumn{1}{c}{ Bahan } & Basis & F1 & F2 & F3 \\
\hline Ekstrak KJN & - & 3 & 6 & 9 \\
Asam stearat & 10 & 10 & 10 & 10 \\
Setil alcohol & 5 & 5 & 5 & 5 \\
Lanolin & 3 & 3 & 3 & 3 \\
Tween 80 & 2,5 & 2,5 & 2,5 & 2,5 \\
Span 80 & 2,5 & 2,5 & 2,5 & 2,5 \\
Nipagin & 0,18 & 0,18 & 0,18 & 0,18 \\
Nipasol & 0,02 & 0,02 & 0,02 & 0,02 \\
Tokoferol & 0,05 & 0,05 & 0,05 & 0,05 \\
Akuades & ad 100 & ad 100 & ad 100 & ad 100 \\
\hline
\end{tabular}

Bahan yang merupakan fase minyak yaitu asam stearat, setil alkohol, nipasol, span 80 dan lanolin dimasukkan ke dalam beker gelas lalu dipanaskan pada suhu $70^{\circ} \mathrm{C}$. Kemudian bahan yang merupakan fase air yaitu nipagin, tween 80 dan aquadest dipanaskan pada suhu $70^{\circ} \mathrm{C}$. Fase air dimasukkan ke dalam fase minyak sedikit-sedikit sambil diaduk hingga terbentuk emulsi. Ekstrak KJN dilarutkan dengan etanol beberapa tetes, dimasukkan basis dan diaduk hingga homogen. Terakhir ditambahkan tokopherol dan aduk hingga homogen. Krim siap dianalisis

\section{Uji evaluasi dan stabilitas sediaan krim}

Uji ini dilakukan berdasarkan pengaruh stress suhu (freeze thaw) di mana sebagai kontrol disimpan pada suhu $25^{\circ} \mathrm{C}$ dan untuk siklus freeze thaw sediaan disimpan pada suhu $40^{\circ} \mathrm{C}$ pada 48 jam pertama dan suhu $40^{\circ} \mathrm{C}$ pada 48 jam berikutnya. Siklus freeze thaw terdiri dari satu rentang waktu penyimpanan pada suhu $40^{\circ} \mathrm{C}$ (Chory, et al., 2015).

\section{Pengamatan organoleptis}

Analisis organoleptis dilakukan dengan mengamati perubahan bentuk, warna dan bau dari sediaan sebelum dan sesudah penyimpanan.

\section{Pemeriksaan Homogenitas}

Uji homogenitas dilakukan dengan cara mengoleskan sampel sebanyak 0,1 gram pada gelas objek lalu diamati. Uji ini dilakukan untuk melihat apakah terdapat bagian yang tidak tercampurkan dengan baik.

\section{Pengukuran pH}

Pengukuran $\mathrm{pH}$ dilakukan sebelum dan sesudah penyimpanan dengan cara mencelupkan kertas $\mathrm{pH}$ ke dalam masing-masing sediaan.
Pengukuran $\mathrm{pH}$ dilakukan untuk mengetahui kesesuaian $\mathrm{pH}$ sediaan dengan $\mathrm{pH}$ kulit. $\mathrm{pH}$ sediaan topikal yang baik berada pada rentang 4,5-6,5 (Aulton, 2005).

\section{Uji daya sebar}

Sebanyak 0,5 gram sediaan diletakkan di atas kaca berukuran $20 \times 20 \mathrm{~cm}$. Selanjutnya ditutupi dengan kaca yang lain dengan ukuran yang sama dan diletakkan pemberat diatasnya hingga bobot mencapai 125 gram dan kemudian diukur diameter setelah didiamkan selama 1 menit. Daya sebar yang baik adalah $5-7 \mathrm{~cm}$ (Voight, 1995).

\section{Pengukuran viskositas}

Viskositas sediaan diukur dengan menggunakan viskometer. Krim dimasukkan dalam beaker glass, selanjutnya pasang spindel nomor 64, lalu spindel diturunkan sampai batas spindel tercelup pada sediaan krim, kemudian dinyalakan dengan ditekannya tombol on. Kecepatan alat diatur mulai 0,3 rpm. Dari msingmasing pengukuran dengan perbedaan kecepatan rpm dibaca skalanya hingga jarum merah yang bergerak telah stabil.

\section{Uji aktivitas antioksidan}

Dibuat deret konsentrasi dengan menimbang sampel krim secara saksama sebanyak 0,5 g dan dilarutkan dalam etanol hingga $20 \mathrm{ml}(25 \mathrm{mg} / \mathrm{mL})$ sebagai larutan induk masing-masing sampel formula ditimbang 2 kali. Jika larutan keruh, maka disentrifus dengan kecepatan 3000 rpm selama 5 menit. Kemudian dibuat 4 deret konsentrasi dengan replikasi pengukuran 3 kali tiap konsentrasi. Pengujian aktivitas antioksidan dilakukan dengan mengukur masing-masing deret konsentrasi sebanyak 1,0 ml dimasukkan ke dalam vial 
tertutup aluminium foil, ditambahkan $4,0 \mathrm{ml}$ larutan DPPH 40 ppm. Dikocok hingga homogen, kemudian diinkubasikan selama 30 menit. Dibuat larutan blangko dengan mengukur $1,0 \mathrm{ml}$ etanol dan 4,0 ml larutan DPPH $40 \mathrm{ppm}$, dikocok hingga homogeny dan diinkubasikan selama 30 menit, Kemudian diukur serapannya pada panjang gelombang $500-600 \mathrm{~nm}$.

Besarnya aktivitas antioksidan dihitung dengan rumus :

\author{
Persen Aktivitas Antioksidan (\% \\ penghambatan $)=\frac{\text { serapan kontrol-serapan sampel }}{\text { serapan kontrol }} \times$ \\ $100 \%$
}

Regresi linier dari rentang konsentrasi ekstrak vs \% peredaman DPPH digunakan untuk menentukan konsentrasi ekstrak yang dapat meredam $50 \%$ DPPH (nilai $\mathrm{IC}_{50}$ ) .

\section{HASIL}

Tabel 1. Hasil pengamatan organoleptis sediaan krim sebelum dan sesudah uji stabilitas dipercepat selama 5 siklus menggunakan alat climatic chamber.

\begin{tabular}{|c|c|c|c|c|c|c|c|}
\hline \multirow{3}{*}{ No } & \multirow{3}{*}{$\begin{array}{l}\text { For- } \\
\text { mula }\end{array}$} & \multicolumn{6}{|c|}{ Organoleptis } \\
\hline & & \multicolumn{3}{|c|}{$\begin{array}{c}\text { Sebelum pengujian } \\
\text { stabilitas dipercepat }\end{array}$} & \multicolumn{3}{|c|}{$\begin{array}{l}\text { Sesudah pengujian } \\
\text { stabilitas dipercepat }\end{array}$} \\
\hline & & $\begin{array}{l}\text { Konsis- } \\
\text { tensi }\end{array}$ & Warna & Bau & $\begin{array}{l}\text { Konsi- } \\
\text { stensi }\end{array}$ & Warna & Bau \\
\hline 1. & Basis & Semi padat & Putih & Tidak berbau & $\begin{array}{l}\text { Semi } \\
\text { padat }\end{array}$ & Putih & Tidak berbau \\
\hline 2. & $\mathrm{~F} 1$ & Semi padat & $\begin{array}{c}\text { Agak } \\
\text { kuning }\end{array}$ & $\begin{array}{c}\text { Berbau jeruk } \\
\text { lemah }\end{array}$ & $\begin{array}{l}\text { Semi } \\
\text { padat }\end{array}$ & Agak kuning & $\begin{array}{c}\text { Berbau jeruk } \\
\text { lemah }\end{array}$ \\
\hline 3. & $\mathrm{~F} 2$ & Semi padat & $\begin{array}{c}\text { Agak } \\
\text { kuning }\end{array}$ & $\begin{array}{c}\text { Berbau jeruk } \\
\text { lemah }\end{array}$ & $\begin{array}{l}\text { Semi } \\
\text { padat }\end{array}$ & Agak kuning & $\begin{array}{c}\text { Berbau jeruk } \\
\text { lemah }\end{array}$ \\
\hline 4. & F3 & Semi padat & Kuning & $\begin{array}{c}\text { Berbau jeruk } \\
\text { lebih tajam }\end{array}$ & $\begin{array}{l}\text { Semi } \\
\text { padat }\end{array}$ & Kuning & $\begin{array}{c}\text { Berbau jeruk } \\
\text { lebih tajam }\end{array}$ \\
\hline
\end{tabular}

Berdasarkan data pada Tabel 1 menunjukkan bahwa formula yang mengandung ekstrak kulit jeruk nipis berwarna kekuningan dan berbau jeruk baik sebelum dan sesudah penyimpanan dipercepat.

Tabel 2. Hasil pengujian homogenitas sediaan krim sebelum dan sesudah uji stabilitas dipercepat selama 5 siklus menggunakan alat climatic chamber

\begin{tabular}{|c|c|c|c|c|}
\hline No & Formula & $\begin{array}{c}\text { Sebelum pengujian } \\
\text { stabilitas dipercepat }\end{array}$ & $\begin{array}{c}\text { Setelah pengujian } \\
\text { stabilitas dipercepat }\end{array}$ & Persyaratan \\
\hline 1. & Basis & Homogen & Homogen & \multirow{4}{*}{$\begin{array}{c}\text { Sediaan menunjukkan } \\
\text { susunan yang homogen } \\
\text { dan tidak terlihat adanya } \\
\text { butiran kasar. }\end{array}$} \\
\hline 2. & $\mathrm{~F} 1$ & Homogen & Homogen & \\
\hline 3. & $\mathrm{~F} 2$ & Homogen & Homogen & \\
\hline 4. & F3 & Homogen & Homogen & \\
\hline
\end{tabular}

Hasil uji homogenitas baik sebelum penyimpanan maupun setelah penyimpanan menunjukkan bahwa sediaan yang dibuat tetap homogen

Tabel 3. Hasil pengukuran daya sebar sediaan krim sebelum dan sesudah uji stabilitas dipercepat selama 5 siklus menggunakan alat climatic chamber.

\begin{tabular}{ccccc}
\hline No & Formula & $\begin{array}{c}\text { Sebelum pengujian } \\
\text { stabilitas dipercepat } \\
(\mathbf{c m})\end{array}$ & $\begin{array}{c}\text { Setelah pengujian } \\
\text { stabilitas dipercepat } \\
(\mathbf{c m})\end{array}$ & Persyaratan \\
\hline 1 & Basis & 5,97 & 5,92 & \multirow{2}{*}{$5-7 \mathrm{~cm}$} \\
\hline 2 & F1 & 5,95 & 5,81 & \\
\hline 3 & F2 & 5,63 & 5,61 & \\
\hline 4 & F3 & 4,92 & 4,98 & \\
\hline
\end{tabular}


Formula krim yang dibuat semuanya memenuhi syarat daya sebar yang baik, baik sebelum dan sesudah penyimpanan. Daya sebar F3 tetap dianggap memenuhi syarat karena ukuran daya sebar telah mendekati nilai persyaratan daya sebar sediaan krim.

Tabel 4. Hasil Pengamatan viskositas sediaan krim sebelum dan sesudah uji stabilitas dipercepat selama 5 siklus menggunakan alat climatic chamber.

\begin{tabular}{|c|c|c|c|c|}
\hline No & Formula & $\begin{array}{l}\text { Sebelum pengujian } \\
\text { stabilitas dipercepat }\end{array}$ & $\begin{array}{c}\text { Setelah pengujian } \\
\text { stabilitas dipercepat }\end{array}$ & Persyaratan \\
\hline 1. & Basis & $2011 \mathrm{cP}$ & $1983 \mathrm{cP}$ & \multirow{4}{*}{$2000-4000 \mathrm{cP}$} \\
\hline 2. & F1 & $2379 \mathrm{cP}$ & $2436 \mathrm{cP}$ & \\
\hline 3. & $\mathrm{~F} 2$ & $2459 \mathrm{cP}$ & $2491 \mathrm{cP}$ & \\
\hline 4. & F3 & $3237 \mathrm{cP}$ & $3169 \mathrm{cP}$ & \\
\hline
\end{tabular}

Formula krim yang dibuat semuanya memiliki viskositas sesuai persyaratan viskositas yang baik, baik sebelum dan sesudah penyimpanan.

Tabel 5. Hasil pengukuran pH sediaan krim sebelum dan sesudah uji stabilitas dipercepat selama 5 siklus menggunakan alat climatic chamber.

\begin{tabular}{ccccc}
\hline No & Formula & $\begin{array}{c}\text { Sebelum pengujian } \\
\text { stabilitas dipercepat }\end{array}$ & $\begin{array}{c}\text { Setelah pengujian } \\
\text { stabilitas dipercepat }\end{array}$ & Persyaratan \\
\hline 1 & Basis & 3,90 & 4,04 & \\
\hline 2 & F1 & 5,37 & 5,34 & \multirow{2}{*}{$4,5-6,5$} \\
\hline 3 & F2 & 5,11 & 5,16 & \\
\hline 4 & F3 & 4,45 & 4,47 & \\
\hline
\end{tabular}

Hasil uji pH formula krim sebelum dan sesudah penyimpanan memiliki pH sesuai dengan pH kulit.

Tabel 6.Hasil uji aktivitas antioksidan formula tunggal ekstrak kulit jeruk nipis

\begin{tabular}{|c|c|c|c|c|c|c|}
\hline Formula & $\begin{array}{c}\text { Konsentrasi } \\
\text { Ekstrak KJN }\end{array}$ & $\begin{array}{l}\text { Rep- } \\
\text { likasi }\end{array}$ & Persamaan gar & $S$ regresi & $\begin{array}{c}\text { IC } 50 \\
(\mathrm{mg} / \mathrm{ml})\end{array}$ & $\begin{array}{c}\text { IC50 } \\
\text { rata-rata }\end{array}$ \\
\hline \multirow{4}{*}{ F1 } & \multirow{4}{*}{$3 \%$} & 1 & $\mathrm{y}=1,5901 \mathrm{x}$ & $+4,597$ & 28,55 & \multirow{4}{*}{28,24} \\
\hline & & & $\mathrm{R}^{2}=0,9836$ & & & \\
\hline & & 2 & $y=1,6336 x$ & 4,37 & 27,93 & \\
\hline & & & $\mathrm{R}^{2}=0,9881$ & & & \\
\hline \multirow{3}{*}{$\mathrm{F} 2$} & \multirow{3}{*}{$6 \%$} & 1 & $\mathrm{y}=1,8131 \mathrm{x}$ & 7,41 & 23,49 & \multirow{3}{*}{22,97} \\
\hline & & & $\mathrm{R}^{2}=0,9926$ & & & \\
\hline & & 2 & $\begin{array}{l}\mathrm{y}=1,7955 \mathrm{x} \\
\mathrm{R}^{2}=0,9902\end{array}$ & $+9,675$ & 22,46 & \\
\hline \multirow{4}{*}{ F3 } & \multirow{4}{*}{$9 \%$} & 1 & $\mathrm{y}=3,0872 \mathrm{x}$ & $+4,605$ & 14,70 & \multirow{4}{*}{14,80} \\
\hline & & & $\mathrm{R}^{2}=0,9967$ & & & \\
\hline & & 2 & $y=3,0296 x$ & $+\quad 4,885$ & 14,89 & \\
\hline & & & $\mathrm{R}^{2}=0,9842$ & & & \\
\hline
\end{tabular}

Hasil uji aktivitas antioksidan menunjukkan bahwa semakin besar konsentrasi ekstrak kulit jeruk nipis, maka aktivitas antioksidannya semakin kuat.

\section{PEMBAHASAN}

Pemeriksaan sifat fisik dan stabilitas sediaan krim dilakukan baik sebelum maupun sesudah penyimpanan dipercepat. Hasil pemeriksaan menunjukkan bahwa secara organoleptik krim yang dihasilkan berwarna kuning dan beraroma jeruk yang berasal dari ekstrak kulit jeruk nipis (Citrus aurantifolia) yang ditambahkan. Semakin besar konsentrasi ekstrak, warna dan aroma jeruk semakin kuat.Uji fisik lainnya menunjukkan bahwa formula krim yang dihasilkan stabil dalam penyimpanan, dan seluruh parameter uji sifat fisik memenuhi syarat sediaan topical sebagai kosmetik. Karena itu, formulasi krim ekstrak kulit jeruk nipis ini dapat dilanjutkan ke uji aktivitas antioksidannya.

Antioksidan adalah zat yang dapat 
menunda, memperlambat, dan mencegah terjadinya proses oksidasi serta menetralisir radikal bebas. Antioksidan menstabilkan radikal bebas dengan melengkapi kekurangan elektron radikal bebas. Dari semua metode uji in vitro, metode pengujian DPPH (1,1 Difenil-2picryhidrazil) adalah metode yang paling banyak digunakan karena lebih mudah, akurat, efisien, sederhana dan cepat dalam penentuan aktivitas antioksidan. Aktivitas antioksidan ditentukan berdasarkan nilai $\mathrm{IC}_{50}$ terhadap radikal bebas DPPH, yang bertujuan untuk mengetahui konsentrasi sediaan yang dapat menghambat $50 \%$ radikal bebas DPPH.

DPPH merupakan radikal bebas yang stabil pada suhu kamar dan sering digunakan untuk mengevaluasi aktivitas antioksidan senyawa atau bahan alam. Larutan DPPH berwarna violet yang memberikan serapan kuat pada panjang gelombang $517 \mathrm{~nm}$. Senyawa antioksidan menyebabkan elektron radikal bebas DPPH menjadi berpasangan yang ditandai dengan penghilangan warna yang sebanding dengan jumlah elektron yang diambil.

Formulasi sediaan topikal yang mengandung Antioksidan diharapkan mampu melindungi kulit dari efek yang tidak diharapkan dari radikal bebas sinar matahari, dimana bentuk sediaan krim adalah yang lebih praktis (Ngozi, 2009). Krim merupakan sediaan semisolid, dalam bentuk emulsi dengan kandungan air tidak kurang dari $60 \%$ dan ditujukan untuk pemakaian luar. Sediaan krim lebih dipilih karena lebih menyenangkan, mudah menyebar rata, dan praktis digunakan (Ansel, 2008)

Hasil penelitian terhadap aktivitas antioksidan krim ekstrak kulit jeruk nipis (Citrus aurantifolia) terhadap radikal bebas DPPH menunjukkan bahwa formula 1 dengan konsentrasi ekstrak 3\% memberikan nilai $\mathrm{IC}_{50}$ rata-rata sebesar $28,24 \mathrm{mg} / \mathrm{ml}$; formula 2 dengan konsentrasi ekstrak $6 \%$ memberikan nilai $\mathrm{IC}_{50}$ rata-rata sebesar $22,97 \mathrm{mg} / \mathrm{ml}$; dan formula 3 dengan konsentrasi ekstrak $9 \%$ memberikan nilai $\mathrm{IC}_{50}$ rata-rata sebesar $14,80 \mathrm{mg} / \mathrm{ml}$. Dari hasil pengujian aktivitas krim antioksidan terhadap radikal bebas DPPH untuk masing-masing formula F1, F2, dan F3 menunjukkan bahwa semakin tinggi konsentrasi ekstrak kulit jeruk nipis, aktivitas antioksidan formula semakin kuat. Hal ini dibuktikan dengan nilai $\mathrm{IC}_{50}$ yang semakin kecil, yang menunjukkan bahwa konsentrasi krim formula 3 yang dapat mengikat $50 \%$ DPPH lebih kecil dari formula 1 dan formula 2. Berdasarkan nilai $\mathrm{IC}_{50} \mathrm{~F} 3$ tersebut, menunjukkan bahwa sediaan krim yang dihasilkan masinh memiliki aktivitas antioksidan yang tidak aktif, sehingga untuk meningkatkan aktivitas antioksidan dari sediaan krim perlu dilakukan kombinasi dengan ekstrak bahan lain yang memiliki aktivitas antioksidan yang kuat. Berdasarkan hasil penelitian ini menunjukkan bahwa krim ekstrak kulit jeruk nipis dapat dikembangkan sebagai krim antioksidan. Mengingat kulit jeruk nipis merupakan limbah yang meruah di lingkungan yang pemanfaatannya hanya untuk memperoleh mimyak atsiri sebagai pemberi aroma tetapi juga memberikan manfaat yang lebih banyak.

\section{KESIMPULAN}

Ekstrak kulit jeruk nipis dapat diformulasikan menjadi sediaan krim dengan tipe M/A terhadap konsentrasi ekstrak $3 \%, 6 \%$ dan $9 \%$, dimana memenuhi syarat kestabilan fisik berdasarkan parameter uji organoleptik, homogenitas, $\mathrm{pH}$ dan viskositas. Formula 3 adalah formula terbaik dengan aktivitas antioksidan paling besar dengan nilai $\mathrm{IC}_{50}$ sebesar 14,80 $\mathrm{mg} / \mathrm{ml}$.

\section{SARAN}

Perlu dilakukan penelitian lanjutan untuk mengoptimalkan aktivitas antioksidan ekstrak kulit jeruk nipis dengan meningkatkan konsentrasi atau dengan mengkombinasinya dengan senyawa antioksidan dari ekstrak alami lainnya.

\section{DAFTAR PUSTAKA}

Ansel, H. C., 2008, Pengantar Bentuk Sediaan Farmasi, ed IV, Alih bahasa Ibrahim, F. Jakarta : UI Press.

Astarini, F.N.P., Burhan, R.Y.P., Yulvi, Z. 2010. Minyak Atsiri Dari Kulit Buah Citrus grandis, Citrus aurantium (L.) dan Citrus aurantifolia (rutaceae) sebagai Senyawa Antibakteri Dan Insektisida. Prosiding KIMIAFMIPA ITS, Surabaya.

Aulton, M., and Summers M., 2013. Tablet and Compaction. In: Pharmaceutics The Science of Dosage Form Design, 4th. Philadelphia: Churchill Livingstone

Badan Litbang Pertanian, 2013, Jajar Legowo, Badan Penelitian dan Pengembangan Pertanian. Kementrian Pertanian

Banjarnahor, S., \& Artanti, N., 2014. Antioxidant Properties of Flavonoids. Medical Journal of Indonesia, 23(4), 239244.,https://mji.ui.ac.id/journal/index.ph p/mji/issue/view/96 (diakses 15 Juli 2019)

Bernatoniene, J. . et al. 2011. Topical application of calendula officinalis (L.): Formulation 
and evaluation of hydrophilic cream with antioxidant activity, Journal of Medicinal Plants Research, 5(6) : 868-77.

Hindun, Rusdiana, Abdasah, dan Hindritiani, 2017, Potensi Limbah Kulit Jeruk Nipis (Citrus auronfolia) sebagai Inhibitor Tirosinase, IJPST, vol 4, No. 2, http://jurnal.unpad.ac.id/ijpst/article/vie w/12642/6935, (diakses 20 Juli 2019)

Ngozi, I. M. (2009). Chemical Profile of Chromolaena odorata L. (King and Robinson) Leaves. Pakistan Journal of Nutrition. 8 (2).

Nurisyah dan Asmawiyah, 2018, Uji Aktivitas Antioksidan Ekstrak Etil Asetat Limbah Kulit Buah Jeruk Nipis (Citrus aurantifolia S.) Yang Berwarna Hijau Dan Kuning Dengan Metode Dpph (1,1Difenil,2-Pikrilhidrasil), KTI, Poltekkes Kemenkes Makassar
Pinnell. 2003. Evidence-based Herbal Medicines. Philadelphia: Hanley and Belfus 387-395.

Poljsak, B., Dahmane, R., 2012. Free Radicals and Extrinsic Skin Aging. Dermatology Research and Practice. http://dx.doi.org/10.1155/2012/135206 (diakses 15 Juli 2019)

Treml, J., \& Smejkal, K., 2016. Flavonoids as Potent Scavengers of Hydroxyl Radicals. Comprehensive Reviews in Food Science and Food Safety, 15, 720-738.. https://onlinelibrary.wiley.com/doi/abs/1 0.1111/1541-4337.12204 (diakses 07 Juli 2019)

Voigt. 1995. Buku Pelajaran Teknologi Farmasi. Universitas Gajah Mada Press.https://doi.org/10.1016/j.jiph.2015. 01.007

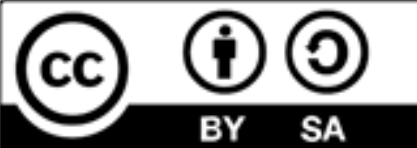

